\title{
Discriminating cool-water from warm-water carbonates and their diagenetic environments using element geochemistry: the Oligocene Tikorangi Formation (Taranaki Basin) and the dolomite effect
}

\author{
STEVEN D. HOOD \\ CAMPBELL S. NELSON \\ PETER J. J. KAMP \\ Department of Earth Sciences \\ University of Waikato \\ Private Bag 3105 \\ Hamilton, New Zealand
}

\begin{abstract}
Fields portrayed within bivariate element plots have been used to distinguish between carbonates formed in warm- (tropical) water and cool- (temperate) water depositional settings. Here, element concentrations $(\mathrm{Ca}, \mathrm{Mg}$, $\mathrm{Sr}, \mathrm{Na}, \mathrm{Fe}$, and $\mathrm{Mn}$ ) have been determined for the carbonate fraction of bulk samples from the late Oligocene Tikorangi Formation, a subsurface, mixed dolomite-calcite, cool-water limestone sequence in Taranaki Basin, New Zealand. While the occurrence of dolomite is rare in New Zealand Cenozoic carbonates, and in cool-water carbonates more generally, the dolomite in the Tikorangi carbonates is shown to have a dramatic effect on the "traditional" positioning of coolwater limestone fields within bivariate element plots. Rare undolomitised, wholly calcitic carbonate samples in the Tikorangi Formation have the following average composition: Mg 2800 ppm; Ca 319100 ppm; Na 800 ppm; Fe 6300 ppm; Sr $2400 \mathrm{ppm}$; and Mn $300 \mathrm{ppm}$. Tikorangi Formation dolomite-rich samples ( $>15 \%$ dolomite) have average values of: Mg 53400 ppm; Ca 290400 ppm; Na 4700 ppm; Fe 28100 ppm; Sr 5400 ppm; and Mn 500 ppm. Elementelement plots for dolomite-bearing samples show elevated $\mathrm{Mg}, \mathrm{Na}$, and $\mathrm{Sr}$ values compared with most other low-Mg calcite New Zealand Cenozoic limestones. The increased trace element contents are directly attributable to the trace element-enriched nature of the burial-derived dolomites, termed here the "dolomite effect". Fe levels in the Tikorangi Formation carbonates far exceed both modern and ancient cool-water and warm-water analogues, while $\mathrm{Sr}$ values are also higher than those in modern Tasmanian cool-water carbonates, and approach modern Bahaman warm-water carbonate values. Trace element data used in conjunction with more traditional petrographic data have aided in the diagenetic interpretation of the carbonate-dominated Tikorangi sequence. The geochemical results have been particularly useful for providing more definitive evidence for deep burial dolomitisation of the deposits under the influence of marine-modified pore fluids.
\end{abstract}

Keywords carbonate geochemistry; trace elements; coolwater limestone; dolomite; Tikorangi Formation; Oligocene; Taranaki Basin; New Zealand; reservoir

G03066; Online publication date 1 December 2004 Received 22 August 2003; accepted 5 March 2004

\section{INTRODUCTION}

Over the past two decades, a variety of facies characteristics have been documented to distinguish between shelf limestones deposited in warm (tropical) sea water from those formed in cool (temperate) water (e.g., Nelson 1988; James 1997) (Table 1). Rao (1996) in particular has advocated that the element geochemistry ( $\mathrm{Ca}, \mathrm{Mg}, \mathrm{Sr}, \mathrm{Na}, \mathrm{Fe}, \mathrm{Mn}$ ) of limestones may also be used to differentiate these depositional settings, as well as to help elucidate their subsequent diagenetic evolution (e.g., Morse \& Mackenzie 1990; Winefield et al. 1996). Here we document the trace element geochemistry of the non-tropical Oligocene Tikorangi Formation carbonates from Taranaki Basin, western North Island of New Zealand, partly to increase our understanding of their diagenesis from that gained from previous petrographic study (Hood et al. 2003b, 2004), but mainly to gauge the influence of their dolomite content on the usefulness of trace elements for discriminating between warm-water and cool-water carbonate facies.

\section{PETROLOGICAL BACKGROUND FOR TIKORANGI FORMATION}

The latest Oligocene Tikorangi Formation is a subsurface (c. $3 \mathrm{~km}$ depth), fractured carbonate reservoir in Taranaki Basin (King \& Thrasher 1996; Hood et al. 2003a,b). Rocks comprise a spectrum of siliciclastic through carbonate dominated facies formed at temperate latitudes in shelf to basin paleoenvironments (Hood et al. 2003c). Compared with other well-studied New Zealand occurrences of midTertiary cool-water calcitic limestones (e.g., Nelson 1978), the Tikorangi carbonates are distinctive because they include small to moderate quantities of diagenetic dolomite (Hood et al. 2004).

Tikorangi Formation rocks were cemented during burial diagenesis by ferroan low-Mg calcite (1-3 mol\% $\left.\mathrm{MgCO}_{3}\right)$ having slightly to moderately depleted $\delta^{18} \mathrm{O}$ values ( -2 to $-4.3 \%$ o, av. $-3.2 \%$ ) and $\delta^{13} \mathrm{C}$ values $(-0.2$ to -0.9 , av. $-0.45 \%$ ) (Hood et al. 2003b). Pressure-dissolution during burial to several hundred metres produced tight rock fabrics with essentially zero porosity. Original intermediate to high $\mathrm{Mg}$ calcite skeletal fragments (echinoderms, benthic foraminifers, calcareous red algae, some bryozoans) were transformed to more stable low-Mg calcite forms via incongruent dissolution, while rare undissolved aragonitic skeletal fragments (bivalves) were neomorphically transformed to low-Mg calcite (Hood et al. 2003b).

The Tikorangi carbonates include ubiquitous, but generally small quantities (typically $<15 \%$, rarely up to $50 \%$ ) of very fine (20-90 $\mu \mathrm{m})$ euhedral rhombs of ferroan dolomite. The rhombs have dull luminescent Fe-rich cores, and often concentrically zoned bright/dull outers (Fig. 1). The dolomites are non-stoichiometric Ca-rich (av. $58 \mathrm{~mol}_{\%} \mathrm{CaCO}_{3}$ ) and $\mathrm{Fe}$ rich (av. $13 \mathrm{~mol}_{\%} \mathrm{FeCO}_{3}$ ) varieties suggested to have formed 

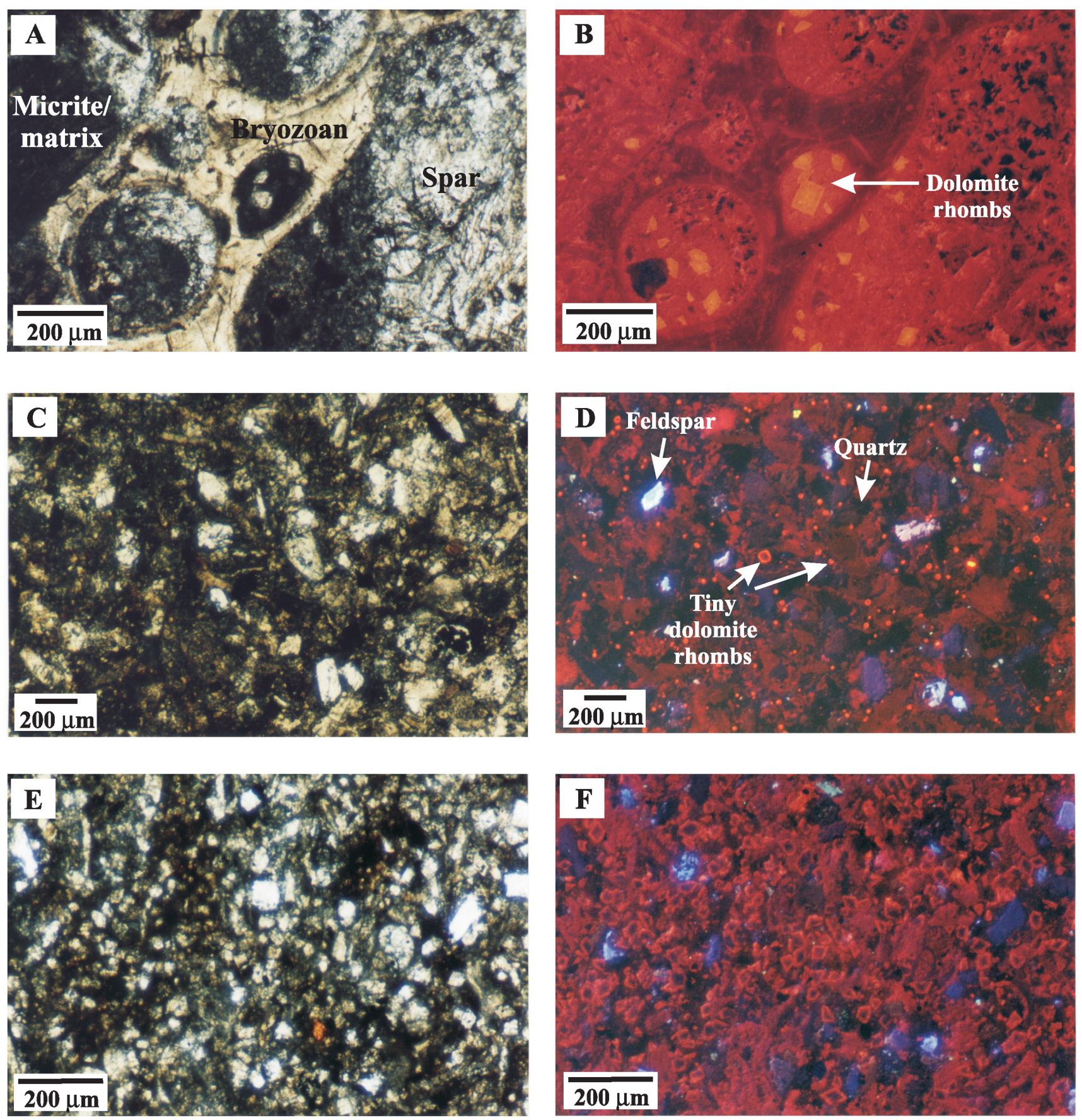

Fig. 1 Photomicrograph pairs under plane polarised light (left) and cathodoluminescence light (right) of selected thin sections of the Tikorangi Formation. A, B, Bryozoan-rich shelfal limestone with dolomite rhombs mimicking original micrite/microsparite fabrics and exhibiting in (B) bright yellow/orange cores and outer zones (W00503). C, D, Tiny scattered euhedral rhombs (C) within siliciclastic/matrix/ micrite-rich areas exhibiting (D) dull luminescent cores enveloped by moderately bright outers (W00562). E, F, Dolomitised limestone showing abundant rhombs with non-luminescent cores and orange-red luminescent outers (W00709).

by selective replacement of micritic and argillaceous matrix materials during burial (Hood et al. 2003b).

The wider geological context of the latest Oligocene (New Zealand Waitakian Stage) Tikorangi Formation in Taranaki Basin is well described by King \& Thrasher (1996), while the stratigraphy, detailed petrography, and fracture and vein mineralisation history of the Tikorangi deposits based upon study of core material from wells in the Waihapa-Ngaere and Maui-1 oilfields are detailed by Hood et al. (2003a,b,c).

\section{TRACE ELEMENTS AS DISCRIMINATORS OF CARBONATE ENVIRONMENTS}

Skeletal differences between shelf carbonates forming in cool water beyond $30^{\circ} \mathrm{N}$ and ${ }^{\circ} \mathrm{S}$ and those forming in warm waters of the tropics have been well documented (e.g., Lees \& Buller 1972; Nelson 1988; Hayton et al. 1995; James 1997) (Table 1). These skeletal differences typically manifest themselves in contrasting primary carbonate mineralogies 

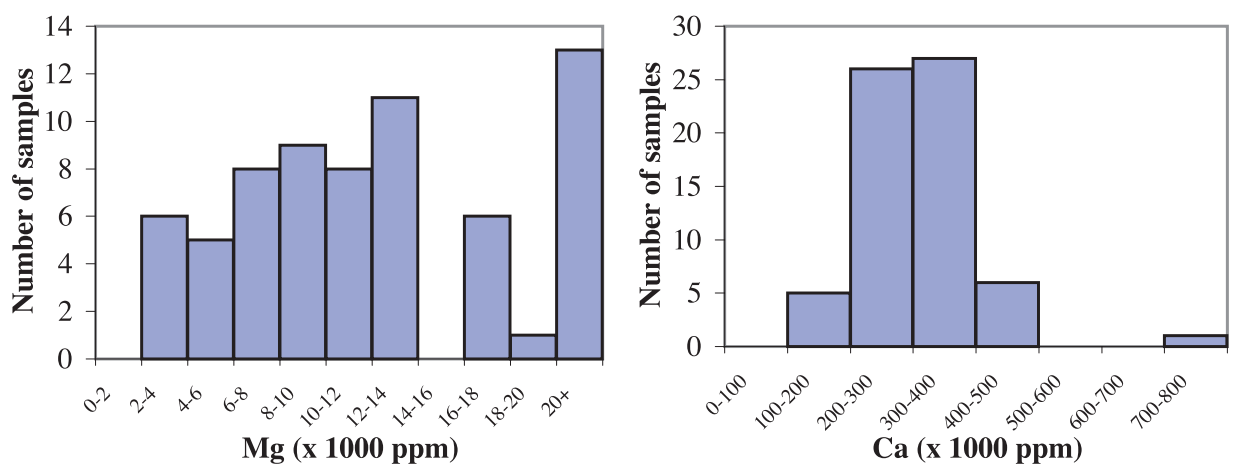

Fig. 2 Histograms displaying the range of trace element concentrations in the carbonate fraction of representative Tikorangi Formation samples.
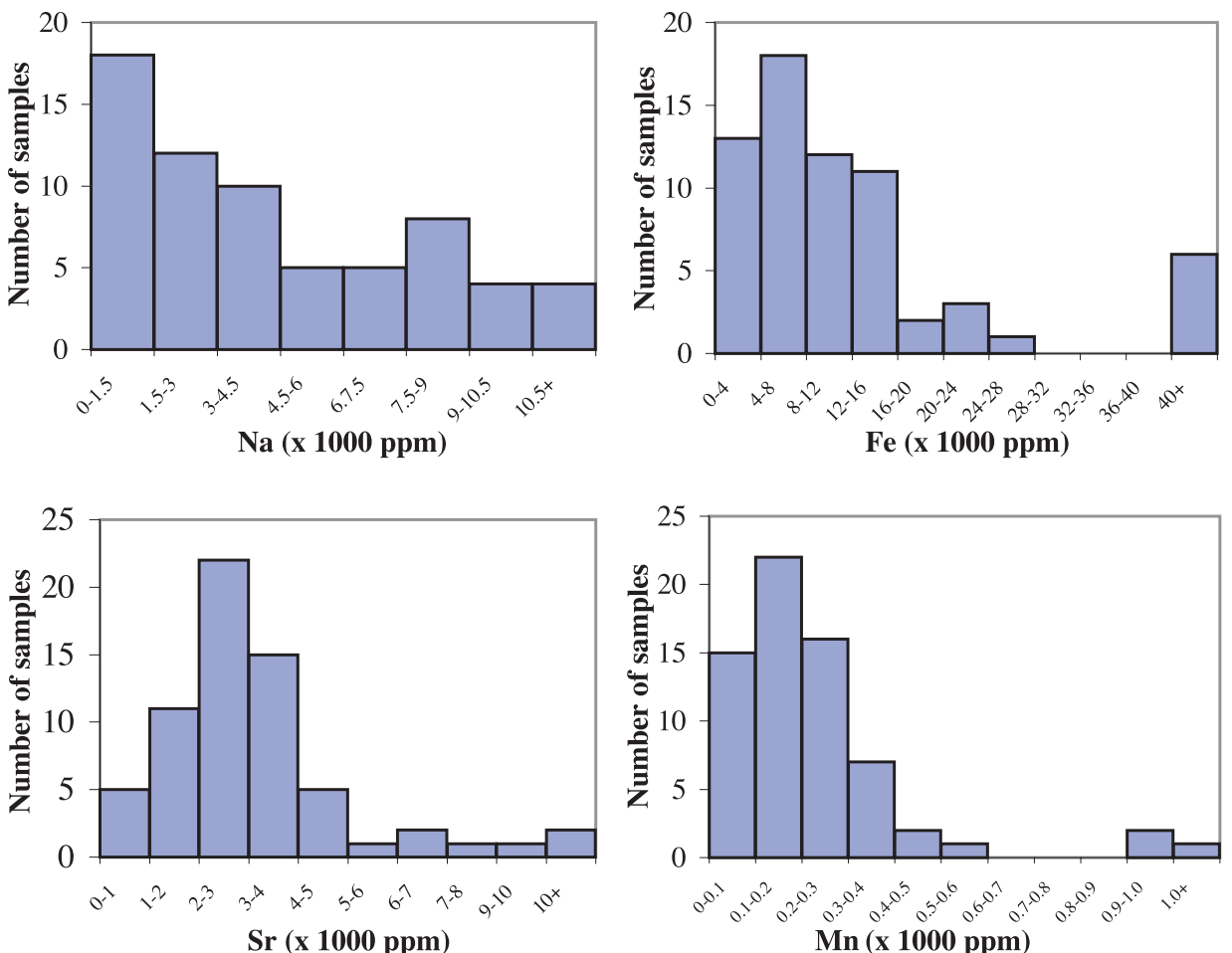

(Rao 1996). High-Mg calcite (HMC; >12 mol\% $\mathrm{MgCO}_{3}$ ) and aragonite are the primary mineralogies in the warm-water (or tropical) skeletal and inorganically precipitated carbonates, while intermediate-Mg calcite (IMC; 4-12 mol\% $\mathrm{MgCO}_{3}$ ) and low-Mg calcite ( $\mathrm{LMC} ;<4 \mathrm{~mol} \% \mathrm{MgCO}_{3}$ ) mineralogies more typically dominate cooler water (temperate) carbonates. Inevitably, these mineralogical contrasts manifest themselves in trace element differences between the warm-water and coolwater carbonates, and thus potentially provide a geochemical approach for distinguishing between these settings in ancient limestones.

Studies of cool-water carbonates are far outnumbered by studies of their warm-water counterparts, and consequently our present understanding of cool-water carbonates is still developing. While cool-water carbonates are beginning to receive greater recognition worldwide (Nelson 1988; James 1997), there is a long way to go to establish their spectrum of origins, including the vexed question of superimposed dolomitisation at temperate latitudes (James et al. 1993; Nicolaides 1997; Kyser et al. 2002). Due largely to the work of Rao (1981, 1986, 1990a,b, 1991, 1996), but also others (e.g., Veizer 1983; Morrison \& Brand 1986; Brand \& Morrison 1987; Morse \& Mackenzie 1990; Winefield et al. 1996), a geochemical approach has evolved to help differentiate calcitic cool-water carbonates from their warmwater counterparts based on trace element composition.

Chemical discrimination between cool-water and warm-water carbonates has been suggested on the basis of characteristic fields within bivariate element plots (Rao 1981, 1986, 1990a,b, 1991; Winefield et al. 1996). Rao (1991) noted that the concentrations of $\mathrm{Na}, \mathrm{Sr}$, and $\mathrm{Mn}$ differed between subtropical, cool-temperate, and subpolar Tasmanian limestones and that element-element plots could be used to discriminate between them. Winefield et al. (1996) found that for New Zealand Cenozoic cool-water limestones, the $\mathrm{Mg}$ and $\mathrm{Sr}$ contents are mainly lower than occur in many warm-water carbonates, while $\mathrm{Na}, \mathrm{Fe}$, and $\mathrm{Mn}$ are relatively higher. In particular, for element-element plots involving $\mathrm{Na}$ and $\mathrm{Sr}$, they noted that the New Zealand limestones plotted well outside the field for warm-water carbonates and within a cool-water field having Sr values of 100-1000 ppm and $\mathrm{Na}$ values of 500-5000 ppm.

Differences in the trace element content of coolwater and warm-water carbonates may not only reflect their paleolatitudinal depositional setting, but also their subsequent diagenetic history. Diagenetic alteration and 
cement formation generally lower the concentrations of $\mathrm{Sr}$, $\mathrm{Mg}$, and $\mathrm{Na}$, but increase the $\mathrm{Fe}$ and $\mathrm{Mn}$ contents (Al-Aasm \& Veizer 1986; Winefield et al. 1996; Al-Aasm \& Packard 2000). Combinations of element-element plots and summary element matrices have been used to help infer diagenetic environments (e.g., Brand \& Veizer 1980; Al Aasm \& Veizer 1986; Brand \& Morrison 1987; Rao 1990a, 1991), including for cool-water limestones in New Zealand (Winefield et al. 1996; Nelson et al. 2003).

\section{METHODOLOGY}

Following standard and cathodoluminescent (CL) thinsection petrography, representative powders of 65 Tikorangi Formation samples (see Hood et al. 2003d) were prepared using a ringmill with a tungsten-carbide head to prevent any iron contamination. Samples were then subject to acid digestion following the procedures of Robinson (1980) and Winefield (1995). Following appropriate dilution, the sample solutions were analysed for $\mathrm{Ca}, \mathrm{Mg}, \mathrm{Na}, \mathrm{Fe}, \mathrm{Sr}$, and Mn using a GBC909AA double beam atomic absorption spectrophotometer. Winefield (1995) provides more specific analytical details. Errors are $\pm 1 \%$ for $\mathrm{Ca}$ and $\mathrm{Mg}$, and $\pm 5 \mathrm{ppm}$ for $\mathrm{Sr}, \mathrm{Na}, \mathrm{Mn}$, and $\mathrm{Fe}$. The predominantly fine-grained nature of the rocks negated the ability to extract microspar cements or individual dolomite rhombohedra from samples, a problem noted for other partially dolomitised fine limestones (Török 2000). The extremely thin $(<5 \mu \mathrm{m})$ CL zonations in the Tikorangi dolomites negated the possibility of obtaining meaningful microprobe data for specific crystal zones, prompting the bulk geochemical approach adopted here.

$\mathrm{X}$-ray diffraction (XRD) of unoriented powder mounts was used to determine the amount of $\mathrm{Mg}$ substitution in calcite and dolomite lattices (Tucker 1988), and of Fe in the dolomite lattice. Mounts were slow scanned at $0.25^{\circ} 2 \theta / \mathrm{min}$, with the addition of an analytical grade $\mathrm{NaCl}$ (halite) spike for accurate determination of peak positions. Calibration curves for estimating dolomite percent in the presence of calcite were taken from Al-Hashimi \& Hemingway (1974) and Lumsden (1979). Displacement of the $d_{104}$ peak of calcite with increasing $\mathrm{mol} \% \mathrm{MgCO}_{3}$ to dolomite is based on the calibration curve of Goldsmith et al. (1961). Displacement of the $d_{104}$ spacing of dolomite relative to $\mathrm{FeCO}_{3} \mathrm{wt} \%$ uses the calibration curve of Al-Hashimi \& Hemingway (1974).

All trace element and mineralogical data are contained in Hood et al. (2003d), and are available on request.
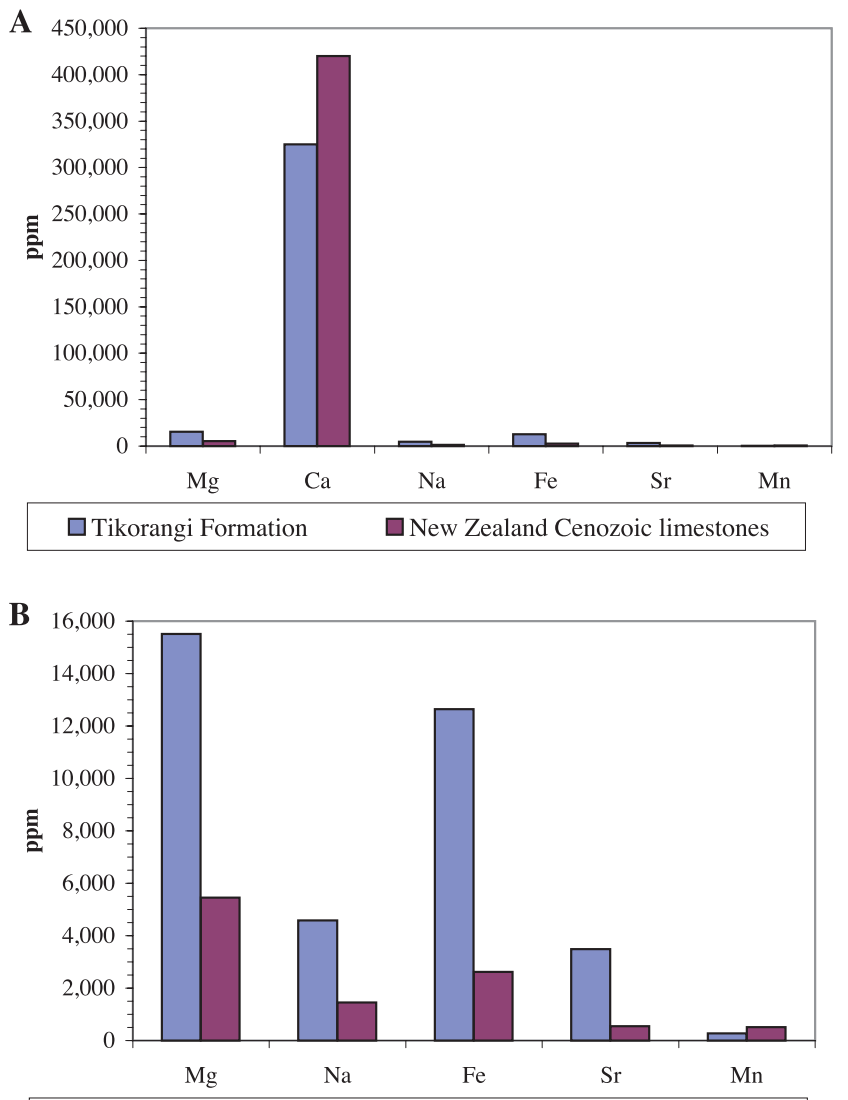

$\square$ Tikorangi Formation $\quad \square$ New Zealand Cenozoic limestones

Fig. 3A, B Comparison of average trace element concentrations in the Tikorangi Formation with those for New Zealand Cenozoic limestones (Table 2) showing (A) the Tikorangi Formation is relatively depleted in $\mathrm{Ca}$, and (B), considerably enriched in $\mathrm{Mg}$ and $\mathrm{Fe}$, with lesser enrichment in $\mathrm{Na}$ and $\mathrm{Sr}$.

\section{ELEMENT GEOCHEMISTRY}

Raw trace element data for the Tikorangi Formation samples are summarised in the histogram plots in Fig. 2. Comparison of the average trace element values for the Tikorangi Formation as a whole with those for the New Zealand Cenozoic coolwater limestone database of Winefield et al. (1996) shows that the Tikorangi carbonates exhibit moderately elevated $\mathrm{Mg}$ and $\mathrm{Na}$ values, and substantially elevated $\mathrm{Fe}$ and $\mathrm{Sr}$ values (Fig. 3; Table 2), despite both being of cool-water (temperate-

Table 2 Summary trace element data for Tikorangi Formation samples.

\begin{tabular}{|c|c|c|c|c|c|c|c|}
\hline & No. of samples & $\mathrm{Mg}$ & $\mathrm{Ca}$ & $\mathrm{Na}$ & $\mathrm{Fe}$ & $\mathrm{Sr}$ & $\mathrm{Mn}$ \\
\hline \multicolumn{8}{|l|}{ Rock type } \\
\hline Mudstone & 2 & 51108 & 196011 & 10987 & 35425 & 3512 & 655 \\
\hline Wackestone & 23 & 15802 & 320454 & 6676 & 16901 & 4318 & 374 \\
\hline Packstone & 15 & 12157 & 292216 & 4037 & 14434 & 3491 & 209 \\
\hline Packstone/grainstone & 14 & 18856 & 305963 & 2969 & 8169 & 2560 & 207 \\
\hline Grainstone & 11 & 9446 & 380267 & 1967 & 5751 & 2218 & 164 \\
\hline Tikorangi Formation average & 65 & 15515 & 325040 & 4589 & 12647 & 3483 & 273 \\
\hline \multicolumn{8}{|l|}{ Carbonate type } \\
\hline Calcite ( $0 \%$ dolomite) & 8 & 2769 & 319139 & 836 & 6313 & 2432 & 343 \\
\hline Mixed calcite/dolomite (5-15\% dolomite) & 24 & 13799 & 295620 & 4996 & 10796 & 3651 & 197 \\
\hline Dolomite-rich ( $>15 \%$ in sample) & 8 & 53431 & 290374 & 4749 & 28118 & 5419 & 503 \\
\hline New Zealand limestone average & 548 & 5508 & 419574 & 1392 & 2428 & 555 & 577 \\
\hline
\end{tabular}




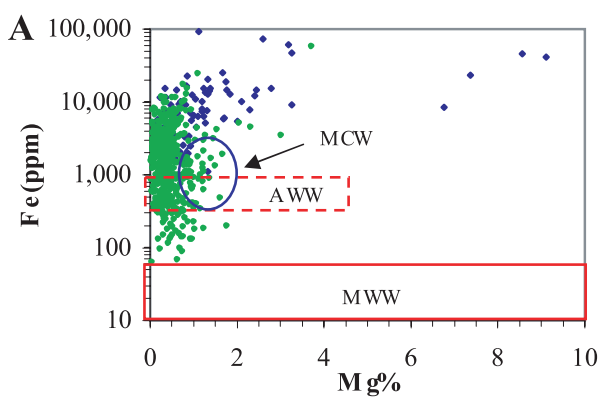

- Tikorangi Formation - New Zealand limestones
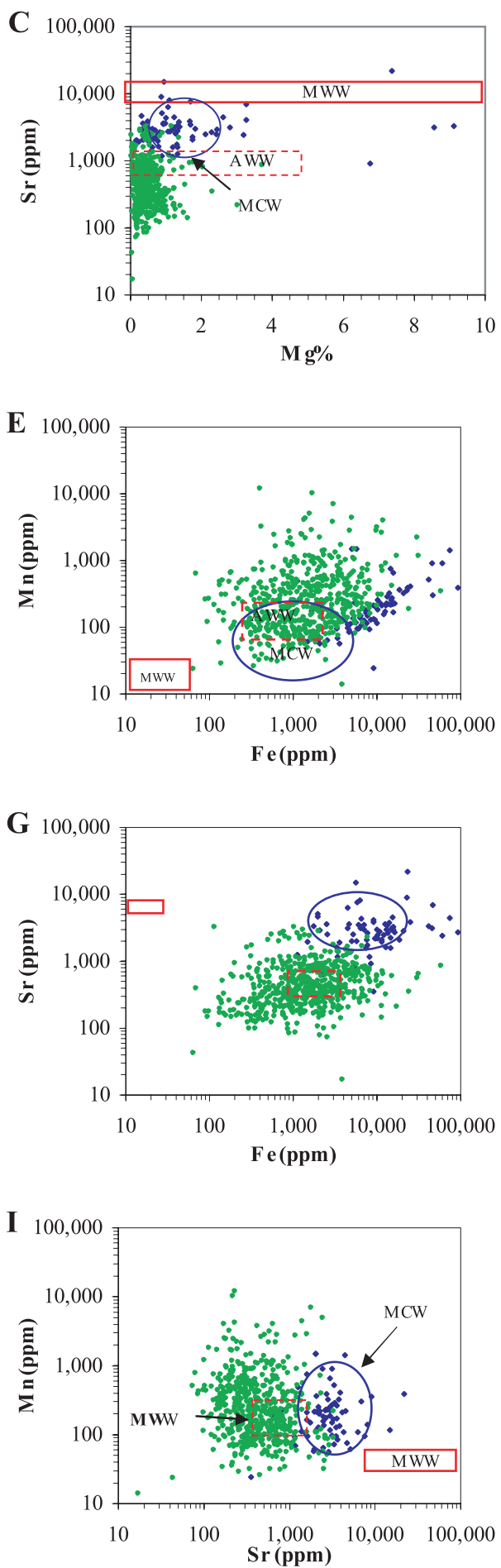
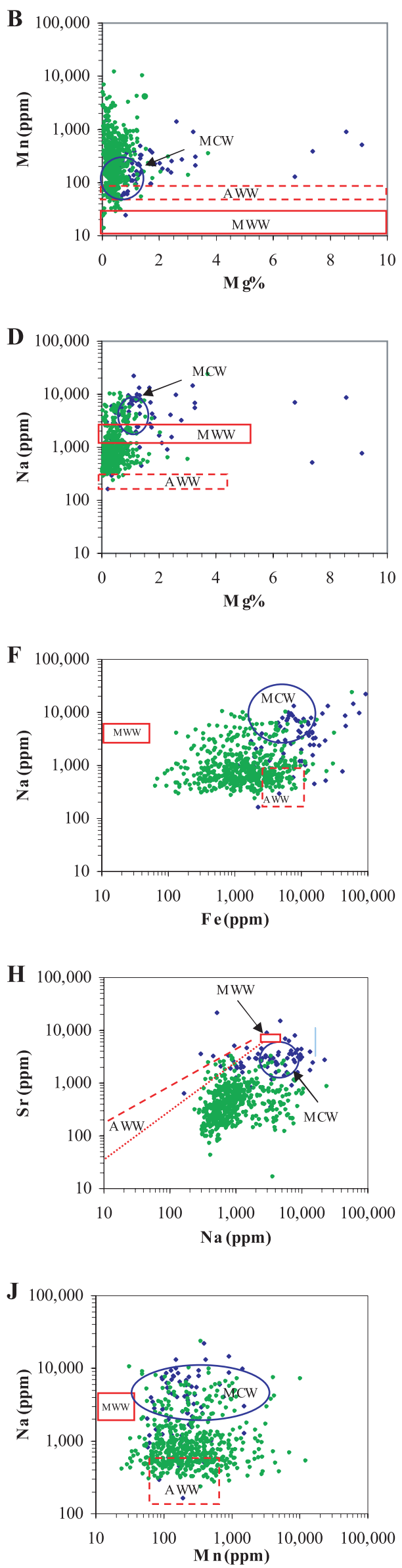

Fig. 4A-J A selection of elementelement plots comparing typical fields for modern warm-water (MWW), modern Tasmanian coolwater $(\mathrm{MCW})$, and Ordovician Tasmanian subtropical shelf carbonates (AWW) with data points for bulk samples of the Tikorangi Formation (blue points) and New Zealand Cenozoic cool-water limestones (green points). Solid red box $=$ modern warm-water Bahaman-type (aragonite + HMC) shelf carbonates; red dashed box $=$ ancient (Ordovician) Tasmanian warm-water shelf limestones; blue ellipse $=$ modern Tasmanian (IMC + LMC) cool-water shelf carbonates. 
Fig. 5 Correlation trends for each of mudstone through grainstone rock types in the Tikorangi Formation based on the average trace element value for each rock type (Table 2). With the exception of $\mathrm{Ca}$, there is a significant decreasing trend in element concentration from mudstone to grainstone. Mst., mudstone; Wst., wackestone; Pst., packstone; Pgst., packstone/grainstone; Gst., grainstone.
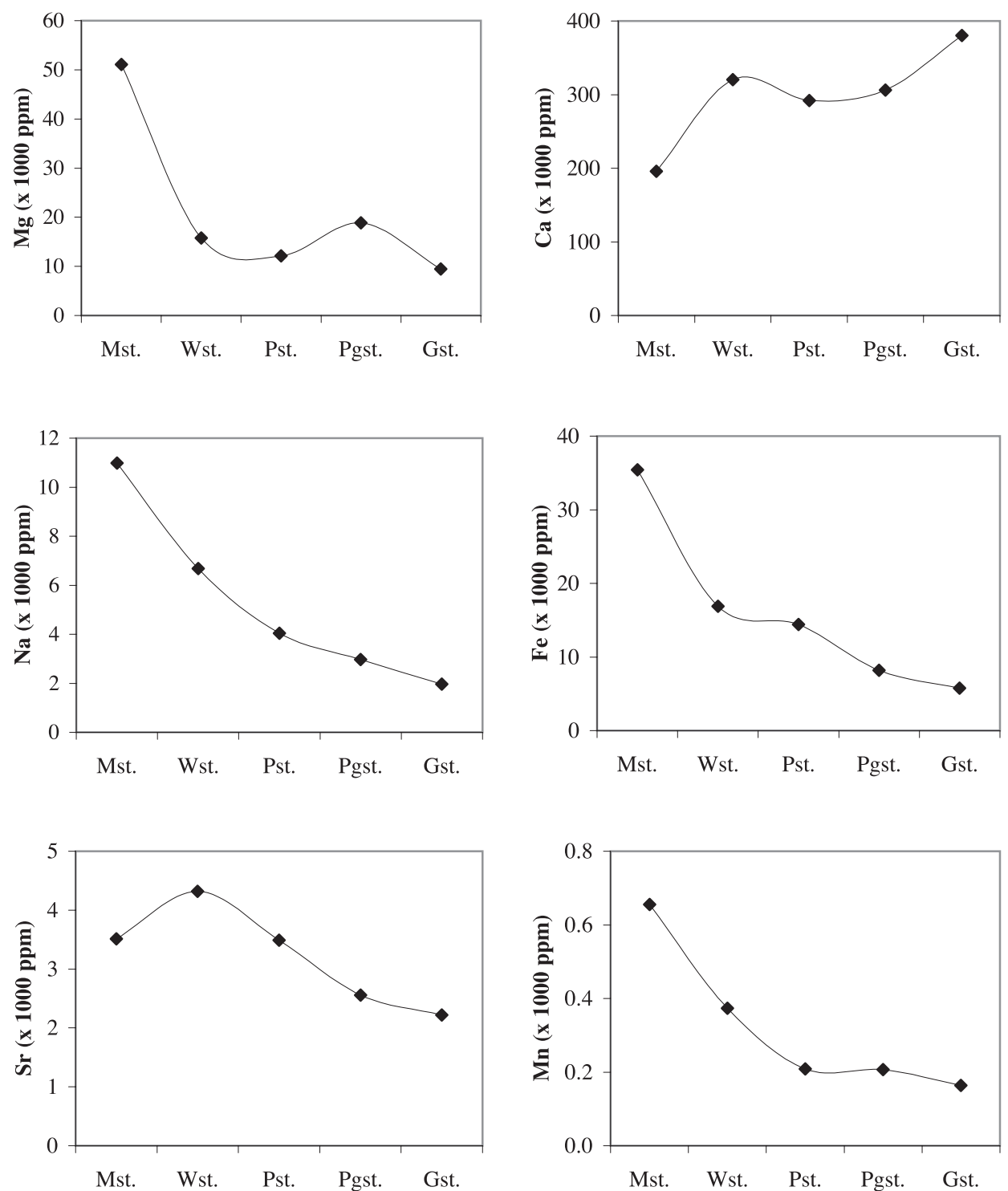

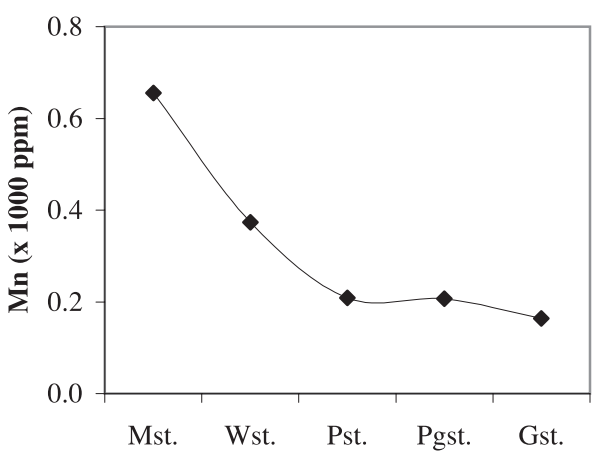

latitude) origin (Hood et. al. 2003a,b,c). Conversely, Ca and Mn values are reduced in the Tikorangi Formation in relation to the New Zealand average.

\section{Comparative plots}

Bivariate trace element plots have been constructed (Fig. 4A-J) to graphically compare the entire Tikorangi Formation trace element database with the entire available New Zealand limestone database, as well as previously suggested fields (Rao 1996) for both modern and ancient warm-water and cool-water carbonates. Display of the entire data as opposed to calculated averages affords a better appreciation of the overall differences in the element distributions. It is evident that the Tikorangi Formation samples commonly have elevated $\mathrm{Mg}$, $\mathrm{Na}$, $\mathrm{Fe}$, and $\mathrm{Sr}$ trace element concentrations compared to the New Zealand Cenozoic limestones, and are nearer to the fields for modern Tasmanian (IMC + LMC) cool-water carbonates and modern warm-water Bahaman (aragonite + HMC) carbonates.

\section{Trace elements versus rock composition}

Comparison of average trace element data for the five main petrographic facies previously identified in the Tikorangi Formation by Hood et al. (2003b) (Table 2) is shown in Fig. 5. This indicates a generally declining $\mathrm{Mg}, \mathrm{Na}, \mathrm{Fe}, \mathrm{Sr}$, and $\mathrm{Mn}$ content, but increasing $\mathrm{Ca}$ content, with passage from matrix/micrite-rich mudstones to sparry grainstones. This facies control on trace element composition has been further investigated by determining the correlation trends between trace element values and various petrographic properties from the same samples (data in Hood et al. 2003d), as summarised in Fig. 6. Correlations between total carbonate percent and each of $\mathrm{Mg}, \mathrm{Na}, \mathrm{Fe}, \mathrm{Sr}$, and $\mathrm{Mn}$ are all negative. However, positive correlations between dolomite percent and these same elements, suggest a likely strong influence by the burialderived diagenetic dolomite in the Tikorangi Formation (Hood et al. 2004). Similar correlations between micrite/matrix and siliciclastic percent and $\mathrm{Mg}, \mathrm{Na}, \mathrm{Fe}, \mathrm{Sr}$, and $\mathrm{Mn}$ result from dolomite being more prevalent in the relatively micrite/clayrich and carbonate-poor facies (Fig. 1). 


\begin{tabular}{|l|c|c|c|c|c|c|}
\hline & $\mathrm{Mg}$ & $\mathrm{Ca}$ & $\mathrm{Na}$ & $\mathrm{Fe}$ & $\mathrm{Sr}$ & $\mathrm{Mn}$ \\
\hline Total carbonate \% & - & + & - & - & - & - \\
\hline Dolomite \% & + & - & + & + & + & + \\
\hline Spar cement \% & - & + & - & - & - & - \\
\hline Micrite/matrix/clay \% & + & - & + & + & + & + \\
\hline Skeletal \% & - & + & - & - & - & - \\
\hline Siliciclastic \% & + & - & + & + & - & \\
\hline
\end{tabular}

Fig. 6 Schematic summary of correlation trends in sample composition versus individual trace elements. Positive and negative values denote the sign of the slope of linear regression lines drawn through the composition versus trace element plots. For example, as total carbonate percent increases, $\mathrm{Mg}$ content decreases. Blank denotes no discernible trend.
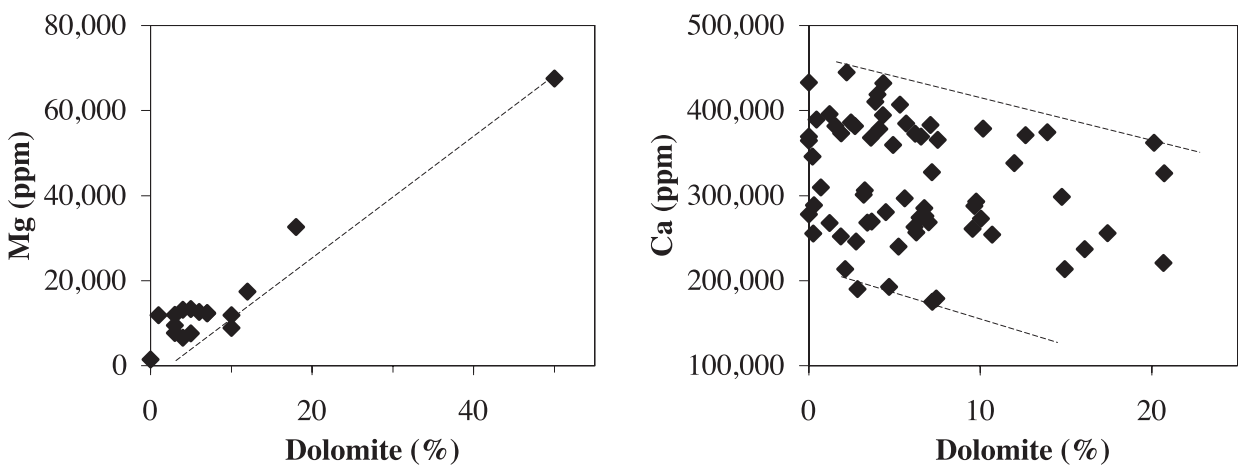

Fig. 7 Correlation fields of dolomite percent and average trace element values for the Tikorangi Formation rocks showing a general trend of increasing trace element concentration with increasing dolomite percent except for $\mathrm{Ca}$.
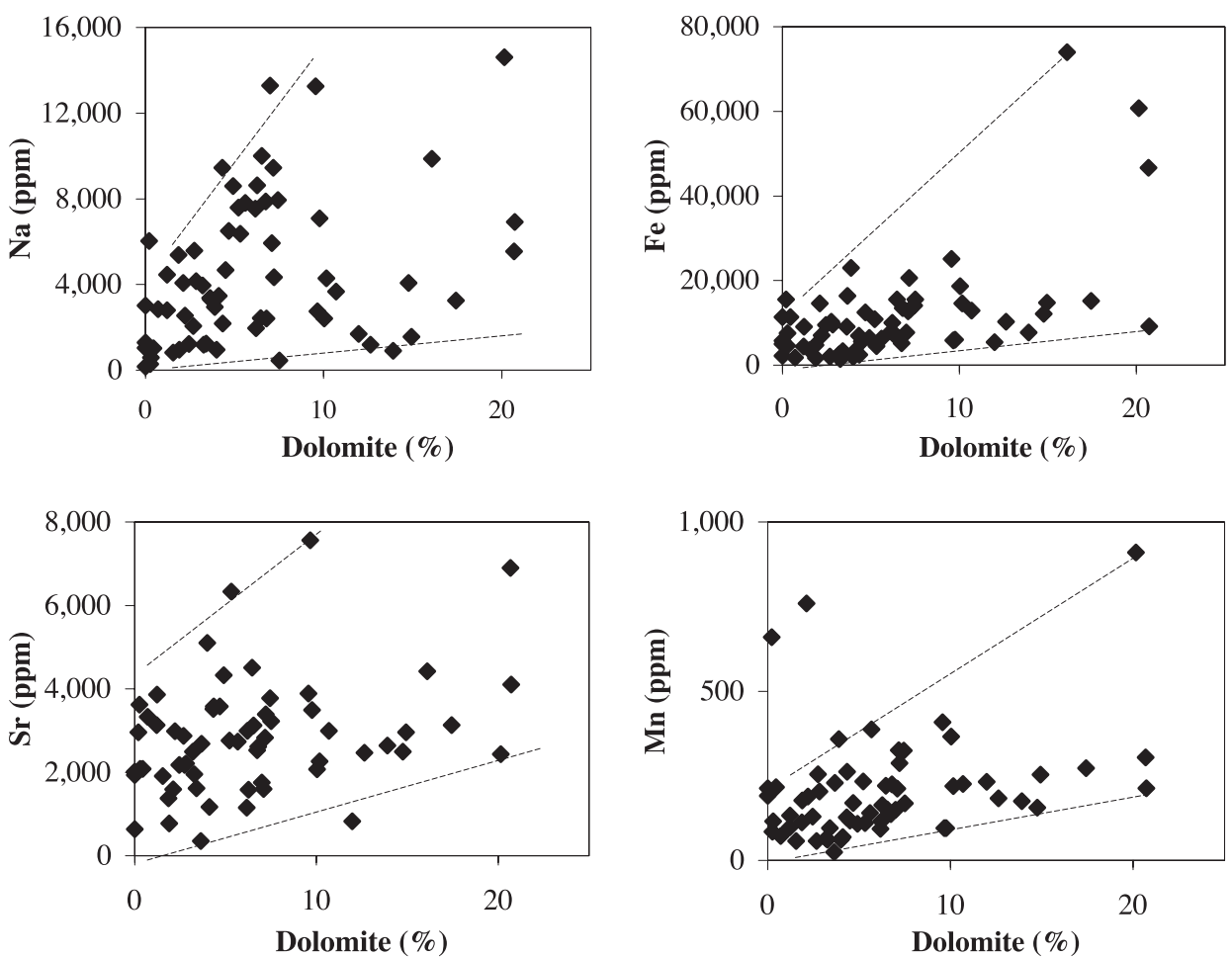


\section{Trace elements versus dolomite content}

The dolomite content of Tikorangi Formation samples most commonly ranges from 5 to $10 \mathrm{wt} \%$, and occasionally reaches as high as 20-50 wt\%. Bivariate plots show the influence of dolomite content on trace element concentrations (Fig. 7). A negative correlation exists with Ca because of $\mathrm{Mg}$ substitution for $\mathrm{Ca}$ in the dolomite lattice. $\mathrm{Na}, \mathrm{Fe}$, and $\mathrm{Mn}$, together with $\mathrm{Mg}$, typically increase in concentration with increasing dolomite content. The Fe trend reflects the fact that the dolomite is iron rich. Mn, a major control in activating cathodoluminescence within the Tikorangi Formation dolomite rhombs (Fig. 1) (Hood et al. 2004), is present in higher quantities in the dolomite-rich rocks compared to the non-dolomite-bearing non-luminescent calcite cements.

\section{Element geochemistry of carbonate mineral phases}

Samples were segregated into three groups based on dolomite contents of $0,5-15$, and $>15 \%$ to best ascertain the "dolomite effect" on trace element geochemistry within the Tikorangi Formation (Table 2). The element histograms in Fig. 8 indicate that variably elevated $\mathrm{Mg}, \mathrm{Na}$, and $\mathrm{Fe}$ contents are associated with the dolomitic groups, while the converse applies for $\mathrm{Ca}$.

\section{GEOCHEMICAL DISCRIMINATION OF DIAGENETIC ENVIRONMENTS}

\section{Diagenetic environments defined}

Shallow burial diagenesis is considered here to involve pore fluids having "near normal" marine salinity (c. 35 ppt) and may involve sub-seafloor depths down to several tens of metres or more. This study uses the term deep burial diagenetic realm when burial depths were sufficient for the onset of chemical compaction as a result of increasing overburden pressure. For carbonate deposits this typically requires a few 100 m of burial (e.g., Hood \& Nelson 1996; Nicolaides \& Wallace 1997; Borre \& Fabricius 1998). By this stage, pore fluid chemistry is usually influenced by increased temperatures and pressures, and possibly salinities, in a strongly reducing environment, involving marine-modified or connate fluids. Meteoric diagenesis is defined here as including meteorically derived fluids introduced into pore spaces in the subsurface, and does not necessarily have to have involved subaerial exposure. The postulated introduction of meteoric fluids into the deeply buried Tikorangi Formation would have necessitated a direct link into the deep subsurface from the upper levels experiencing meteoric circulation via extensive fracture networks within the formation (Hood et al. 2003b).

\section{Summary element matrices}

Element-element plots may be used to help infer the diagenetic environments that have influenced carbonate deposits (Veizer 1983; Morrison \& Brand 1986; Brand \& Morrison 1987; Morse \& Mackenzie 1990; Winefield et al. 1996). The slope of linear regression lines drawn through element-element plots are delineated by positive and negative symbols forming summary element matrices (Fig. 9A). Schematic pie diagrams show the relative influence of each diagenetic regime for an unknown matrix. Summary element matrices were developed by Winefield et al. (1996) for idealised meteoric, marine, and burial diagenetic trends (in this case 100\%).
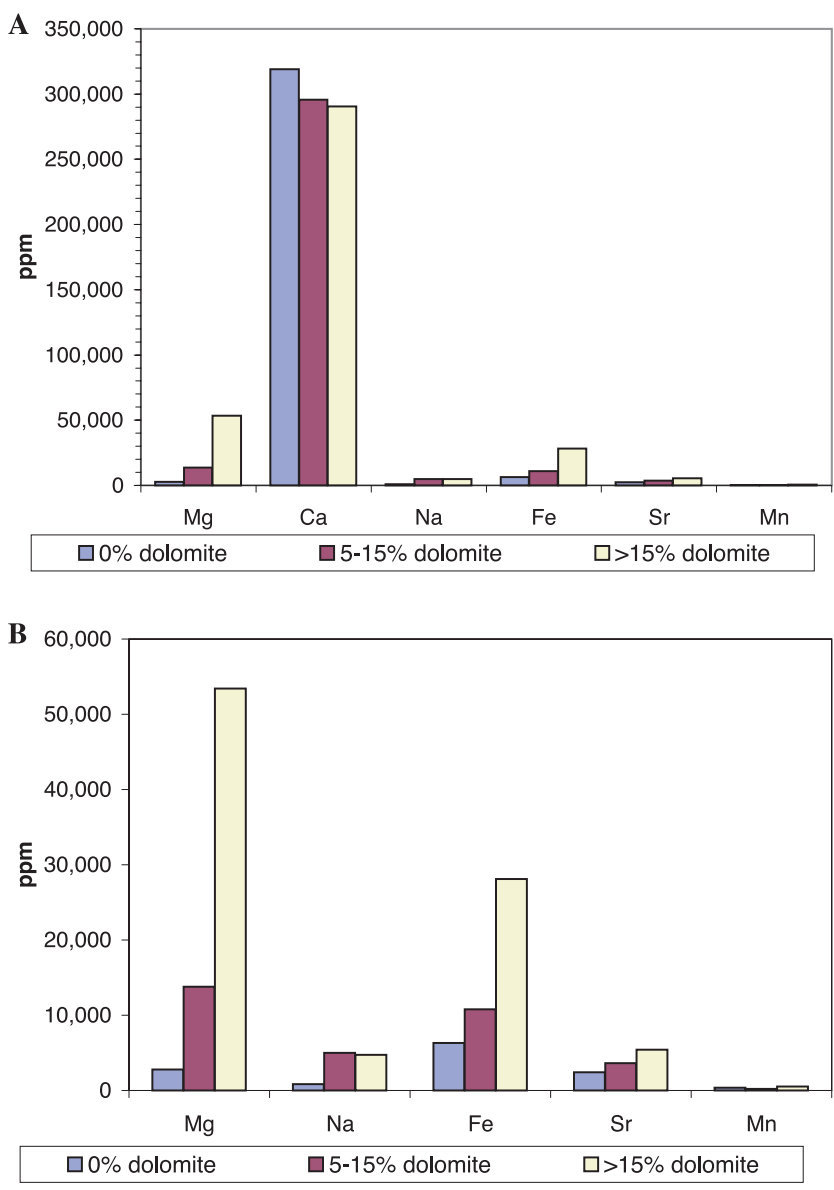

Fig. 8 A, Comparison of trace element concentrations in wholly calcitic, mixed calcitic/dolomitic (5-15\% dolomite), and dolomiticrich ( $>15 \%$ dolomite) limestone samples within the Tikorangi Formation. Note reduced Ca values in dolomitic samples in relation to calcitic ones. $\mathbf{B}$, Trace element enrichment of $\mathrm{Mg}, \mathrm{Na}$, and $\mathrm{Fe}$ occurs in dolomitic samples in relation to calcitic ones, while $\mathrm{Sr}$ and Mn show similar levels across the groups.

The use of the term marine diagenesis by Winefield et al. (1996) was probably inappropriate because strictly it involves only alterations and cements formed in sea water at or very close to the sediment-water interface (Nelson \& James 2000), and not a few to many metres below it. The suggestion of commonly occurring marine diagenesis in New Zealand Cenozoic carbonates by Winefield et al. (1996) is misleading because these limestones only rarely contain marine cements (Hood \& Nelson 1996; Nelson \& James 2000), and they are certainly absent from the Tikorangi Formation. It is suggested here that the bulk of the marine-influenced diagenesis in the Winefield et al. (1996) scheme formed in the shallow burial realm (Hood \& Nelson 1996). Consequently, the concept of marine diagenetic trends inferred from element-element plots is here taken to reflect predominantly shallow burial diagenetic trends. Idealised summary element matrices are shown for meteoric (either within the subaerial or burial setting), shallow burial, and deep burial diagenetic realms in Fig. 9B. The extent of agreement of these "standard" matrices with individual matrices for the Tikorangi Formation rock types has been used to infer their diagenetic evolution, following the approach of Winefield et al. (1996). 


\section{A, Standard element matrices and pie diagrams}

Meteoric

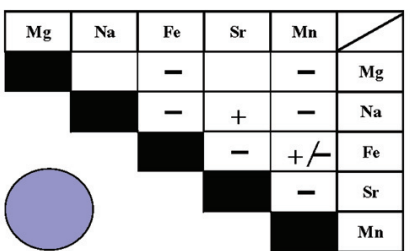

Shallow burial

\begin{tabular}{|c|c|c|c|c|c|}
\hline $\mathrm{Mg}$ & $\mathrm{Na}$ & $\mathrm{Fe}$ & $\mathrm{Sr}$ & $\mathrm{Mn}$ & \\
\hline & & + & & + & $\mathrm{Mg}$ \\
\hline & + & + & + & $\mathrm{Na}$ \\
\hline & & + & - & $\mathrm{Fe}$ \\
\hline & & & + & $\mathrm{Sr}$ \\
\hline & & & & $\mathrm{Mn}$ \\
\hline
\end{tabular}

Deep burial

\begin{tabular}{|c|c|c|c|c|c|}
\hline $\mathrm{Mg}$ & $\mathrm{Na}$ & $\mathrm{Fe}$ & $\mathrm{Sr}$ & $\mathrm{Mn}$ & \\
\hline & & & & & $\mathrm{Mg}$ \\
\hline & + & + & + & $\mathrm{Na}$ \\
\hline & & + & + & $\mathrm{Fe}$ \\
\hline & & & + & $\mathrm{Sr}$ \\
\hline
\end{tabular}

\section{B, Tikorangi formation element matrices}

All Tikorangi rocks

\begin{tabular}{|c|c|c|c|c|c|}
\hline $\mathrm{Mg}$ & $\mathrm{Na}$ & $\mathrm{Fe}$ & $\mathrm{Sr}$ & $\mathrm{Mn}$ & \\
\hline & + & + & + & + & $\mathrm{Mg}$ \\
\hline & + & - & + & $\mathrm{Na}$ \\
\hline
\end{tabular}

$5-15 \%$ dolomite

\begin{tabular}{|c|c|c|c|c|c|}
\hline $\mathrm{Mg}$ & $\mathrm{Na}$ & $\mathrm{Fe}$ & $\mathrm{Sr}$ & $\mathrm{Mn}$ & \\
\hline & - & + & - & + & $\mathrm{Mg}$ \\
\hline & + & - & + & $\mathrm{Na}$ \\
\hline
\end{tabular}

0\% dolomite

\begin{tabular}{|c|c|c|c|c|c|}
\hline $\mathrm{Mg}$ & $\mathrm{Na}$ & $\mathrm{Fe}$ & $\mathrm{Sr}$ & $\mathrm{Mn}$ & \\
\hline & + & + & - & + & $\mathrm{Mg}$ \\
\hline & - & + & + & $\mathrm{Na}$ \\
\hline
\end{tabular}

$>15 \%$ dolomite

\begin{tabular}{|c|c|c|c|c|c|}
\hline $\mathrm{Mg}$ & $\mathrm{Na}$ & $\mathrm{Fe}$ & $\mathrm{Sr}$ & $\mathrm{Mn}$ & \\
\hline & + & + & - & + & $\mathrm{Mg}$ \\
\hline & + & + & + & $\mathrm{Na}$ \\
\hline
\end{tabular}

Fig. 9 A, Summary element matrices for idealised meteoric, shallow burial, and deep burial diagenetic trends. Positive and negative symbols delineate the sign of the slope of linear regression lines drawn through element-element plots. Schematic pie diagrams show the relative influence of each diagenetic regime for an unknown matrix (in this case 100\%). B, Summary element matrices and pie diagrams for all samples of Tikorangi Formation, and those containing $0,5-15$, and $>15 \%$ dolomite showing increased burial influence in the more dolomitic rich rocks.

Summary element matrices for samples containing 0 , $5-15$, and $>15 \%$ dolomite have been derived for the Tikorangi Formation (Fig. 9A) to assess the effect that the presence of dolomite may have on each diagenetic regime (Hood 2000). On this basis, geochemical diagenetic signatures obtained across the range of non-dolomitic to dolomite-rich samples in the Tikorangi carbonates show that deep burial influences dominate in the dolomite-rich samples, but that this influence diminishes in the fully calcitic rocks and in the Tikorangi rocks treated as a whole (Fig. 9B). The element matrices imply that diagenesis in the Tikorangi Formation has experienced a persistent meteoric influence, especially so within the wholly calcitic rock types, but reducing to almost zero with dolomite content.

\section{DISCUSSION}

The trace element geochemistry of the Tikorangi Formation rocks has been shown using element-element plots to have many affinities with modern Tasmanian cool-water LMC and IMC carbonate sediments (Fig. 4, 10), involving elevated Mg, 
Fig. 10 Schematic summary of relative abundances of trace elements in the Tikorangi Formation and comparison with other cool-water and tropical warm-water carbonates. The radius of the circles is roughly proportional to the average concentration of each element in the respective samples. Adapted from Winefield et al. (1996).

\begin{tabular}{|c|c|c|c|c|c|c|}
\hline & & $\mathbf{M g}$ & $\mathbf{N a}$ & $\mathrm{Fe}$ & $\mathbf{S r}$ & Mn \\
\hline \multirow{3}{*}{ 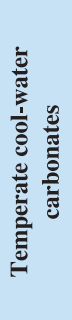 } & $\begin{array}{l}\text { Tikorangi Formation } \\
\text { (Oligocene) }\end{array}$ & & & & & 0 \\
\hline & $\begin{array}{c}\text { New Zealand } \\
\text { (Cenozoic) }\end{array}$ & & 0 & & 0 & 0 \\
\hline & $\begin{array}{l}\text { Tasmanian } \\
\text { (Modern) }\end{array}$ & & & 0 & & $\circ$ \\
\hline \multirow{2}{*}{ 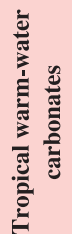 } & $\begin{array}{l}\text { Tasmanian } \\
\text { (Ordovician) }\end{array}$ & & ○ & 0 & 0 & $\circ$ \\
\hline & $\begin{array}{l}\text { Bahaman } \\
\text { (Modern) }\end{array}$ & & & - & & 。 \\
\hline
\end{tabular}

$\mathrm{Na}$, and $\mathrm{Sr}$ values in relation to ancient LMC New Zealand limestones. These elevated element data for $\mathrm{Mg}, \mathrm{Na}$, and $\mathrm{Sr}$ are therefore inconsistent with those derived from wholly calcitic cool-water limestones. Enriched trace element values are directly attributable to the presence of burial-derived dolomite in the Tikorangi Formation, which contrasts with the anticipated lowering of the element concentrations with progressive carbonate diagenesis in calcitic limestones. Indeed, the elevated Mg concentrations "falsely" overlap with modern and ancient warm-water carbonates. The anomalies are due to the presence of dolomite - "the dolomite effect" - in the Tikorangi Formation. Fe levels in the Tikorangi carbonates far exceed both modern and ancient cool-water and warmwater analogues (Fig. 4, 10), particularly so in the dolomiterich samples (Table 2). The source of this Fe enrichment was probably from compaction in interbedded siliciclastic shale-like sequences (Hood et al. 2003a). Elevated Mn levels in the Tikorangi Formation in relation to the New Zealand database are similarly attributable to dolomite formation at considerable depths and elevated temperatures (Hood 2000). $\mathrm{Sr}$ values are enriched in dolomite-bearing facies and are slightly higher than average values for bulk Tasmanian coolwater modern carbonates, approaching values in modern Bahaman carbonates (Fig. 4, 10).

Given the modest proportion of tiny dolomite crystals with typically intricate CL zoning, the bulk geochemical approach can be defended as an evolving technique with the ability to provide perhaps more meaningful data than could have been derived from attempting to microprobe exceedingly thin specific crystal zones. Trace element data used in conjunction with more traditional petrographic data have aided in the diagenetic interpretation of the carbonate-dominated Tikorangi units. Results have been particularly useful for providing more definitive evidence for burial dolomitisation of the deposits and the general nature of associated pore fluids. The summary element matrices (Fig. 9B) suggest that burial influences dominate the diagenetic evolution of dolomite-rich samples while a meteoric influence dominates in the wholly calcitic rocks. Post-lithification fracturing is intensive in the Tikorangi rocks, so that the introduction of pore fluids including a meteoric component is tenable. This may imply dissolution and reprecipitation of small amounts of calcite which have taken on a meteoric diagenetic signature reflected in trace element summary plots. In diagenetic studies of sandstones within Taranaki Basin, late (burial) calcite is thought to have formed in the underlying Eocene Kapuni Group from meteoric-derived fluids (Smale et al. 1999). In the Tikorangi, this may have occurred by slow diffusion of meteoric-tainted fluids, with dissolution and recrystallisation occurring on a micro-scale with no intervening void, after dolomitisation and tectonic fracturing events.

\section{CONCLUSIONS}

1. This study has contributed to the limited trace element database for carbonates generally, and for cool-water carbonates in particular, at the same time providing bulk trace element concentrations for a mixed dolomitecalcite cool-water sequence, the Oligocene Tikorangi Formation. The occurrence of dolomite is rarely reported in New Zealand Cenozoic carbonates, or from cool-water carbonates in general.

2. The "dolomite effect" in the Tikorangi samples is shown here to have had a dramatic influence on the bulk rock trace element geochemistry in comparison with most other cool-water calcitic carbonate occurrences.

3. Consequently, where dolomite is present, caution is needed if trace element data are to be used to help distinguish between ancient carbonates formed in cool-water versus warm-water shelf settings.

4. In the Tikorangi Formation, the trace element geochemistry supports a marine-modified, largely deep-burial origin for the dolomite.

5. Variables in the control of trace element sources within burial-derived dolomites, such as association with siliciclastics as key trace element providers, the openness of the diagenetic system, subsurface temperatures, pressures, and residency time, are all key factors worthy of future study.

\section{ACKNOWLEDGMENTS}

We thank Petrocorp Exploration Ltd, now Shell Petroleum Mining Company Limited, for access to drill core and in-house petroleum reports, and the New Zealand Ministry of Economic Development 
for assistance in the Petroleum Report Library and core storage facilities, Wellington. We acknowledge funding from a University of Waikato Postgraduate Scholarship and the New Zealand Foundation for Research, Science and Technology (contracts UOW815 and UOWX0301). We are grateful to Peter Winefield and an anonymous referee for their constructive review comments of this paper, which prompted some significant revision.

\section{REFERENCES}

Al-Aasm, I. S.; Packard, J. J. 2000: Stabilization of early formed dolomite: a tale of divergence from two Mississippian dolomites. Sedimentary Geology 131: 97-108.

Al-Aasm, I. S.; Veizer, J. 1986: Diagenetic stabilization of aragonite and low-Mg calcite, I: trace elements in rudists. Journal of Sedimentary Petrology 56: 136-152.

Al-Hashimi, W.; Hemingway, J. E. 1974: Recent dolomitization and the origin of the rusty crusts of Northumberland: a reply. Journal of Sedimentary Petrology 44: 271-274.

Borre, M.; Fabricius, I. A. 1998: Chemical and mechanical processes during burial diagenesis of chalk: an interpretation based on specific surface data of deep-sea sediments. Sedimentology 45: 755-769.

Brand, U.; Morrison, J. 1987: Biochemistry of fossil marine invertebrates. Geoscience Canada 14: 85-107.

Brand, U.; Veizer, J. 1980: Chemical diagenesis of a multicomponent carbonate system - I: trace elements. Journal of Sedimentary Petrology 50: 1219-1236.

Goldsmith, J. R.; Graf, D. L.; Heard, H. C. 1961: Subsolidus phase relations in the system $\mathrm{CaCO}_{3}-\mathrm{MgCO}_{3}$. Journal of Geology 69: 45-74.

Hayton, S.; Nelson, C. S.; Hood, S. D. 1995: A skeletal assemblage classification system for cool-water carbonate deposits based on New Zealand Cenozoic limestones. Sedimentary Geology 100: $123-141$

Hood, S. D. 2000: Subsurface stratigraphy and petrology of a cool-water carbonate fracture reservoir - the mid-Tertiary Tikorangi Formation, Taranaki Basin, New Zealand. Unpublished $\mathrm{PhD}$ thesis, lodged in the Library, University of Waikato, Hamilton, New Zealand.

Hood, S. D.; Nelson, C. S. 1996: Cementation scenarios for New Zealand Cenozoic cool-water limestones. New Zealand Journal of Geology and Geophysics 39: 109-122.

Hood, S. D.; Nelson, C. S.; Kamp, P. J. J. 2003a: Lithostratigraphy and depositional episodes of the Oligocene carbonate-rich Tikorangi Formation, Taranaki Basin, New Zealand. New Zealand Journal of Geology and Geophysics 46: 363-386.

Hood, S. D.; Nelson, C. S.; Kamp, P. J. J. 2003b: Modification of fracture porosity by multiphase vein mineralisation in an Oligocene cool-water carbonate reservoir, Taranaki Basin, New Zealand. American Association of Petroleum Geologists Bulletin 87: 1575-1597.

Hood, S. D.; Nelson, C. S.; Kamp, P. J. J. 2003c: Petrogenesis of diachronous mixed carbonate-siliciclastic megafacies in the cool-water Oligocene Tikorangi Formation, New Zealand. New Zealand Journal of Geology and Geophysics 46: $387-405$

Hood, S. D.; Nelson, C. S.; Kamp, P. J. J. 2003d: Depositional and diagenetic characteristics and origin of the Tikorang Formation fractured reservoir, Taranaki Basin, New Zealand. Unpublished open-file petroleum report PR2864. Wellington, Ministry of Economic Development.

Hood, S. D.; Nelson, C. S.; Kamp, P. J. J. 2004: Burial dolomitisation in a cool-water carbonate petroleum reservoir: the Oligocene Tikorangi Formation, Taranaki Basin, New Zealand. Sedimentary Geology 172: 117-138.
James, N. P. 1997: The cool-water carbonate depositional realm. In: James, N. P.; Clarke, A. D. ed. Cool-water carbonates. Society for Sedimentary Geology Special Publication 56: $1-22$.

James, N. P.; Bone, Y.; Kyser, T. K. 1993: Shallow burial dolomitisation and dedolomitisation of mid-Cenozoic, coolwater, calcitic, deep-shelf limestones, southern Australia. Journal of Sedimentary Petrology 63: 528-538.

King, P. R.; Thrasher, G. P. 1996: Cretaceous-Cenozoic geology and petroleum systems of the Taranaki Basin, New Zealand. Institute of Geological \& Nuclear Sciences Monograph 13. Lower Hutt, Institute of Geological \& Nuclear Sciences. $243 \mathrm{p}$.

Kyser, T. K.; James, N. P.; Bone, Y. 2002: Shallow burial dolomitization and dedolomitization of Cenozoic coolwater limestones, southern Australia: geochemistry and origin. Journal of Sedimentary Research 72: 146-157.

Lees, A.; Buller, A. T. 1972: Modern temperate water and warmwater shelf carbonate sediments contrasted. Marine Geology 13: 67-73.

Lumsden, D. N. 1979: Discrepancy between thin section and x-ray estimates of dolomite in limestones. Journal of Sedimentary Petrology 49: 429-436.

Morrison, J. O.; Brand, U. 1986: Geochemistry of Recent marine invertebrates: Geoscience Canada 13: 237-254.

Morse, J. W.; Mackenzie, F. T. 1990: Geochemistry of sedimentary carbonates. Developments in Sedimentology 48. Elsevier, Amsterdam.

Nelson, C. S. 1978: Temperate shelf carbonate sediments in the Cenozoic of New Zealand. Sedimentology 25: 737-771.

Nelson, C. S. 1988: An introductory perspective on cool-water shelf carbonates. Sedimentary Geology 60: 3-12.

Nelson, C. S.; James, N. P. 2000: Marine cements in mid-Tertiary cool-water shelf limestones of New Zealand and southern Australia. Sedimentology 47: 609-630.

Nelson, C. S.; Winefield, P. R.; Hood, S. D.; Caron, V.; Pallentin, A.; Kamp, P. J. J. 2003: Pliocene Te Aute limestones, New Zealand: expanding concepts for cool-water shelf carbonates. New Zealand Journal of Geology and Geophysics 46: 407-424.

Nicolaides, S. 1997: Marine-derived dolomite in the shallowly buried temperate Port Campbell Limestone (Miocene), Otway Basin, Australia. Sedimentology 44: 143-157.

Nicolaides, S.; Wallace, M. W. 1997: Pressure-dissolution and cementation in an Oligo-Miocene non-tropical limestone (Clifton Formation), Otway Basin, Australia. In: James, N. P.; Clarke, A. D. ed. Cool-water carbonates. Society for Sedimentary Geology Special Publication 56: 249-262.

Rao, C. P. 1981: Geochemical differences between tropical (Ordovician) and subpolar (Permian) carbonates, Tasmania, Australia. Geology 9: 205-209.

Rao, C. P. 1986: Geochemistry of temperate-water carbonates, Tasmania, Australia. Marine Geology 71: 363-370.

Rao, C. P. 1990a: Geochemical characteristics of cool-temperate carbonates, Tasmania, Australia. Carbonates and Evaporites 5: 209-221.

Rao, C. P. 1990b: Petrography, trace elements and oxygen and carbon isotopes of Gordon Group carbonates (Ordovician), Florentine Valley, Tasmania, Australia. Sedimentary Geology 66: 83-97.

Rao, C. P. 1991: Geochemical differences between subtropical (Ordovician), temperate (Recent and Pleistocene) and subpolar (Permian) carbonates, Tasmania, Australia. Carbonates and Evaporites 6: 83-106.

Rao, C. P. 1996: Modern carbonates tropical temperate polar. Introduction to sedimentology and geochemistry. Howrah, Tasmania. 
Robinson, P. 1980: Determination of calcium, magnesium, manganese, strontium, sodium and iron in the carbonate fraction of limestones and dolomites: Chemical Geology 28: 135-146.

Smale, D.; Mauk, J. L.; Palmer, J.; Soong, R.; Blattner, P. 1999 Variations in sandstone diagenesis with depth, time, and space, onshore Taranaki wells, New Zealand. New Zealand Journal of Geology and Geophysics 42: 137-154.

Török, A. 2000: Formation of dolomite mottling in Middle Triassic ramp carbonates (southern Hungary). Sedimentary Geology 131: 131-145.

Tucker, M. 1988: Techniques in sedimentology. Oxford, Blackwell Scientific Publications.
Veizer, J. 1983: Chemical diagenesis of carbonates: theory and application of trace element technique. In: Stable isotopes in sedimentary geology. Society of Economic Paleontologists and Mineralogists Short Course 10: 3-100.

Winefield, P. 1995: Elemental geochemistry of cool-water Cenozoic limestones in New Zealand. Unpublished MSc thesis, lodged in the Library, University of Waikato, Hamilton, New Zealand.

Winefield, P. R.; Nelson, C. S.; Hodder, P. W. 1996: Discriminating temperate carbonates and their diagenetic environments using bulk elemental geochemistry: a reconnaissance study based on New Zealand Cenozoic limestones. Carbonates and Evaporites 11: 19-31. 